\title{
RECENZIÓ ANDREJKOVICS ZOLTÁN: A LÁTHATATLAN JÁTÉK - A GYŐZTESEK GONDOLKODÁSMÓDJA AZ E-SPORTBAN CÍMÜ KÖNYVÉRŐL
}

\section{Szerző:}

Papp Dávid

Debreceni Egyetem

Szerző e-mail címe:

papp777david@gmail.com

\section{Lektorok:}

Csukonyi Csilla (PhD)

Debreceni Egyetem

Mező Katalin (PhD)

Debreceni Egyetem

...és további két anonim lektor

Papp Dávid (2020): Recenzió Andrejkovics Zoltán: A láthatatlan játék - A győztesek gondolkodásmódja az e-sportban című könyvéről. Mesterséges intelligencia - interdisz̧ciplináris folyóirat, II. évf. 2020/2. szám. 105-110. doi: 10.35406/MI.2020.2.105

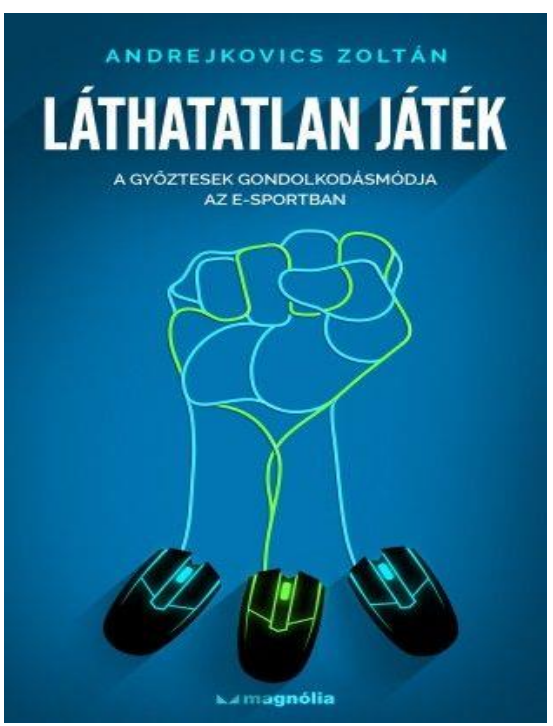

\section{A recenzió alapjául szolgáló mü bibliográfiája:}

Andrejkovics Zoltán (2017): A láthatatlan játék - A győztesek gondolkodásmódja az e-sportban. Agave Könyvek Kiadó Kft., Budapest.

ISBN: 9789634193593

Kulcsszavak: e-sport, gondolkodásmód Diszciplina: informatika, sporttudomány

Andejkovics, Zoltán (2017)? The Invisible Game - The Winners' Mindset in E-Sports. Budapest: Agave Konyvek Kft.

ISBN: 9789634193593

Keywords: e-sport, mindset

Disciplines: informatics, sport science 
A technológia rohamos fejlődésének egyik jeles példája a videójátékok hétköznapivá válása. Azonban további példaként szolgálhat az is, hogy ezen kezdetekben szabadidős tevékenységek sporttá voltak képesek kinőni magukat, miáltal megszületett a profeszszionális videojátékozás, azaz az e-sport. A fiatal sporttípus kutatása, illetve az e-sportolók segítése tudományos szempontból is releváns.

Andrejkovics Zoltán 2017 folyamán megjelent könyvében az utóbbit célozta meg, méghozzá a mentális oldalról megközelítve, pszichológiai tényezőket felsorakoztatva. Ez egy hiánypótló könyv, hiszen sok e-sportoló elveszett annak tekintetében mit is kellene tennie ahhoz, hogy jobb teljesítményt érhessen el, profivá válhasson. Célom azonban a könyv pszichológiai, azon belül sportpszichológiai, szempontú értel-mezése, értékelése.

A szerző a gyakorlati hasznosságot tartotta szem előtt, ezáltal életből vett történeteket használ fel, írásmódja is a könnyen érthetôségre törekszik, az egyes példákat, elméleteket ábrák felhasználásával szemlélteti.

A bevezetés során az e-sportokat a hagyományos sportok közül a szükséges jellemzők mentén a sakkhoz hasonlítja, illetve kiemeli a jellegzetes szerencsefaktort, ami jelen sporttípust áthatja a kiszámíthatatlanságnak és az érdekességnek a fokozása okán van jelen. A fizikai és a mentális felkészülés esetén az utóbbira helyezi a nagyobb hangsúlyt. Kiemeli a tudatosság fontosságát, hiszen a megértésen túl, az alkalmazni tudás is kulcstényező. A mentális, pszichológiai tényezőket a könyv folyamán 12 fejezetre bontja fel, amelyek tartalma röviden a továbbiakban ismertetésre kerül.

Az első fejezet a célok és a célkitűzések címet viseli. A célok meghaladják a vágyakat a megvalósítás kérdésében, a megfogalmazásban rejlik a kulcs. A rövid- és a hosszútávú célok is bemutatásra kerülnek különbség, illetve megfelelőség szempont-jából. A célok megvalósulásának szakaszait a növényültetés metaforájával ragadja meg, a mag elültetésétől a gyümölcsig való eljutással (p. 28-32). Kiemeli a szándék kreatív, teremtő erejét, a nyitott látókörűség előnyét, a magasztos célok bátorító hatását, ahogy azt is, milyen fontos, hogy mindig legyenek céljaink, amint elérünk egyet, akár rövid-, akár hosszútávú az, ideje újat kitűzni.

A felkészülés mentális oldala fejezet a gyakorlás folyamatára helyezi a hangsúlyt. A profivá válás kemény munka, szüntelen gyakorlás, a hibák pedig tanulási lehetőségek. A csapat mögötti tudást, tartalmat és potenciált egy jéghegy metaforával ragadja meg ( $\mathrm{p}$. 40). A gyakorlás hatásosságának pilléreit, melyeket részletekben ki is fejt, négy fö pontban ragadja meg: I. A gyakorlással eltöltött valós idő; II. Egy adott gyakorlat ismétlésszáma; III. A gyakorlatok minősége; IV. Kitartás (p. 42-45). Kitér a fejlődés lépcsőzetes voltára, a túlgyakorlásra, mint a siker egyik kulcstényezőjére, a relaxációs idő megtalálására, ami a megújulást segíti elő, viszont az adott e-sportoló teherbírás szintén kiemelt tényező. Minden azonban az alapok megfelelő elsajátításán múlik, így azokat automatizmus szintig kell begyakorolni, az 
ismétlésszám pedig a kulcsot jelenti a tökéletesség eléréséhez. Az edzést is ugyanúgy komolyan kell venni, mint egy tétmérkőzést, a rutinos csapatok erősségét pedig a tapasztalatok mennyisége jelenti.

Hangsúlyt fektet a pozitív megerősítés, így a dicséret hasznosságára mind a magunk, mind a csapattársaink motiválásának terén, ahogy arra is, milyen fontos az intuítiv cselekvéseinknek való tér engedés, így tudjuk kamatoztatni a gyakorlás során elsajátítottakat, illetve figyelhetünk aktívan a játékra.

A taktika és stratégia, mint az e-sport magja kerül említésre a következő fejezetben. Kiemeli, mennyire hasznos az arany középút megtalálása, hiszen 3-5 stratégia ismerete és begyakorlása kulcsfontosságú, természetesen az alapstratégiára fektetve a legnagyobb hangsúlyt, de a „B” és „C” terv jó begyakorlása és ismerete is mérvadó, hiszen bajnokság folyamán egy stratégia folyamatos alkalmazása kiszámíthatóvá teszi a csapatot. Az első percekben a jó stratégia megválasztása pedig jelentheti a különbséget győzelem és vereség között. A stratégiákat értelmezni és elemezni is tudni kell, ehhez három faktort vázol fel, aszerint milyen igény jellemzi az adott stratégiát: 1. Figyelemszükséglet 2. Technikai bonyolultság 3. A csapatjáték szükséglete. A stratégia változtatásnak két okát említi, egyrészről, ha a csapat holtponton van, másrészről ha a stratégia rossz irányba visz minket. Ezeken kívül a fejezet folyamán több általánosan alkalmazható stratégiát, taktikát vázol fel, amelyeket e-sportok fényében mutat be, illetve hangsúlyt fektet az ellenfél játékból való tanulásra fontosságára is (p. 65-68).
A negyedik fejezet az értékekrôl és a csapatról szól. Kiemelésre kerül, hogy vannak egyéni értékeink és olyan értékek is amelyek csapat szinten megegyeznek, így közösek. Az utóbbiak a csapat identitását alakítják ki. Kitér a közös célok, szokások, a csapat-szellem motiváló, előremozdító hatására, hiszen így érhető el a szinergia, a " $110 \%$-os" teljesítménye a csapatnak. Az e-sport csapatot egy versenyhajóhoz hasonlítja, így beszél a szerepekről is, és a tipikusan felmerülő problémákról egyaránt (p. 75-76). Így a csapat harmóniát emeli ki, mint kulcs-tényezőt az előrehaladáshoz, amit a közösen eltöltött idővel lehet elérni. A fejlődésre képes, profivá válás potenciáljával rendelkező e-sportolót jellemző tulajdonságokra is kitér, mint az alázatosság, a szerénység, az ellenfél tisztelete, az egyenlőség eszméjének képvi-selése, az őszinteség (magunkkal szemben is). Visszatekint a taktikák mentén a felvételek visszanézésére és kielemzésére is, nem csak a saját csapat, de az ellenfél játékát tekintve egyaránt.

A motiváció, kiváltképp a teljesítménymotivációról beszélve, a gyermekkorig követi vissza, mivel a szülők példát mutatnak ebben is, ́́gy alakul a ránk jellemző kitartás és türelem is. Ez alapján a motivációt egy tábortűz mintájára mutatja be (p. 87-88). Nagy jelentőséget tulajdonít a sikerélményeknek is, hiszen ezen visszajelzések adhatják számunkra azt az érzést, érdemes a tevékenységet csinálnunk, folytatnunk. Az embereket motiváló tényezőket, illetve szükségleteket szintén az e-sportokra levetítve sorolja fel (p. 89-91). Kitér a belső és a külső motiváltság témájára is, az előbbit a tökéle-tességre való 
törekvéshez, kreatív megoldá-sokhoz, míg az utóbbit a kitartáshoz köti. Ezen kívül szót ejt a példaképek motiváló hatásáról, a sportokban rejlő mûvészeti analógiákról, végül a motivációs beszédekről, mint a teljesítmény növelésének potenciális eszközéről.

Az énről szóló fejezetben énünket a figyelemre vágyás oldaláról fogja meg, illetve a figyelem kivívásáért jellemző viselkedés szemszögéből. Ezt szintén a gyermekkorból vezeti le, hiszen sok esetben a figyelemfelhívó viselkedésünk sokszor nem igazán sajátunk, hanem eltanult, itt külön kitér a Berne (1964) által megfogalmazott és összegyűjtött “emberi játszmák”-ra, amelyekből néhányat részletesen be is mutat (p. 100-103). Ezen gondolatmenet mentén vázolja fel az általa elkülönített belső ént, a külső éntől, vagy az ő szavaival egotól. A két én közötti különbségeket egy táblázatban sorolja fel (p. 107). Kiemeli, hogy mindkét énre kifejezett szükségünk van a sikerhez, méghozzá harmónia létrehozása által. A mások hibáztatása mentén kitér a jellegzetes tüköreffektusra, tehát amik másokban zavarnak minket, azok saját el nem fogadott tulajdonságainkat jelentik. A fejezet zárásaként az élet értelmét, a célunkat az életben, boncolgatja, aminek konklúziója, hogy az gazdagít igazán bennünket, ha élményeinket meg tudjuk másokkal osztani, illetve ha magasztos célért küzdünk.

Az érzékelés témakörét az emberi figyelemmel ragadja meg, főként a jelen állapotára való aktív figyelem fontosságával. Kiemel olyan jellegzetes gátakat, amelyek megaka-dályoznak bennünket a jelen állapotával való aktív törődésben, a terveink megvalósításában.
Tanácsot ad abban, hogyan csende-síthetjük le az elménket, mi által kerülhetünk a Csíkszentmihályi (1991) által megfogal-mazott Flow, vagy áramlat élménybe, mi segíthet megtapasztalni a figyelem lehető legteljesebb spektrumát. Kitér az első gondolat, vagyis az intuitív döntések hasznosságára, a sémákon alapuló gyors döntéshozás előnyére, így az egyszerűségre való törekvésre egyaránt, a remény előtérbe helyezésére a félelemmel szemben. Fontos jellemző a siker-hez az, ha egy lépéssel a versenytársunk előtt tudunk lenni, azaz valamilyen szinten képe-sek legyünk az ô fejével gondolkodni. Végezetül az apró jelek és a véletlenekre helyezi a hangsúlyt itt összegyújtve, hogy mit is jelent, ha egy csapat a játék történéseivel szinkronban van, és ebben mi lehet a segítségükre.

$\mathrm{Az}$ érzelmeink fejezetben a játék során megjelenő tipikus érzelmek felsorolásán (p. 132) túl arról is részletesen szót ejt, hogy ezen érzelmek, miből eredeztethetőek, és mire milyen hatást gyakorolnak. Például a harag esetén a kreativitás és a logikus gondol-kodás nehézségét emeli ki. Fontos szempont-ként szól arról, hogy az érzelmeink minden külső kiváltó tényezőtől függetlenül csak és kizárólag a sajátjaink, így mi is tudjuk őket kezelni, feldolgozni és egyben elfogadni. Ezzel kapcsolatban részletezi, milyen éles különbség van az érzelmek átélése, illetve elfojtása közötti következményekben. Az elfogadásra, főként a tudatos elfogadásra és annak hogyanjára, nagyobb hangsúlyt fektet, így például a Kübler-Ross modell (Kübler-Ross, 2009) alapján az elfogadás szakaszait is bemutatja (p. 139-142). Az érzelmi gátakról szólva kiemeli, hogy ezeket szintén gyermek- 
korban kezdődően építjük ki, ám mennyivel hasznosabb ha őszintén át tudjuk élni érzelmeinket, és a győzelmeknek is őszintén tudunk örülni. Fontos saját érzelmeink tudatos átélése, azok pozitív módon történő felhasználása, de így mások érzelmeinek felismerése is. Az érzelmeket pólus szempontjából a megítélése szerint, jobb nem jó és rossz végletre osztani, hanem az érzelemben rejlő potenciál szerint skála mentén (szerző gondolatmenetét követve hőmérō jelleggel) értékelni. Példát szolgáltat a konstruktív csapatmegbeszélésekről, azok során a moderátor feladatáról. A negatív attitűdök, illetve érzelmi tüskék azonosításával és feloldásával zárja jelen fejezetet.

A gondolatainkat szintén a korábbi belső én és ego párhuzamban közelíti meg. Az utóbbi gondolatai a gyakrabban használtak, ám lassúak és kifejezetten rutinszerúek, míg a belső gondolatokban gyorsaság, kreativitás rejlik, ezek az intuitív módon jelentkező gondolatok, melyek elsőre nem feltétlen tűnnek odaillőnek, vagy logikusnak, azonban hasznos ezekre hallgatni. A fejezet másik nagyobb témája a pozitívan megfogalmazott állításokban jelentkezik, mivel ezen gondolatok segítenek minket előre, tudnak ösztönözni, míg a tagadás csapdába ejthet. Így ilyen szempontból a szerző a tagadó gondolatok mögött megbújó szokásokban való változtatást javasol. A fejezet zárásául pedig egy fontos elv fogalmazódik meg, miszerint nem az a fontos mások mit gondolnak rólunk, hanem az, mi mit gondolunk önmagunkról.

A következő fejezet frappáns címe a „győztesként felkelni”. A szerző itt kitér a teljesítmény hullámzó jellegéről, amely egy alapvetően természetes dolog. A folyamatos edzés mellett a relaxáció, a megfelelő alvás kulcsszerepéről ír, hiszen ezek is a felkészülést szolgálják. Ezt követően olyan tényezőkről ír, mik is lehetnek befolyással, illetve mik segíthetnek a versenymérkőzés sikerében. A mentalitás terén fontos, hogy nem a győzelem a lényeg, hanem, hogy mindent beleadjunk. Alakítsunk ki rutinokat, rituálékat melyek segítenek az ellazulásban és a figyelem koncentrálásában, használjunk „varázs- és hívószavakat", mint a dicséret, az utasítás, vagy az előhívás. Fontos, hogy higgyünk magunkban és abban amire képesek vagyunk, legyünk magabiztosak. A motivációs beszéd, a dúdolás, a megfelelő folyadékfogyasztás, mind segíthet, abban hogy az izgalom ne hátráltasson, hanem hozzájáruljon teljesítményünkhöz. Ahogy azt is kiemeli, hogy a pontoknak is örülni kell, hiszen ez az interakció is hatással lehet ránk, csapatunkra és ellenfeleinkre egyaránt. A fejlődés a kulcs, nem a győzelem maga, a győzelem eredmény és visszajelzés arról, hogy jó úton haladsz.

A kapcsolat a közönséggel fejezet egy kicsit kitekintés jellegü, hiszen ebben a rövid fejezetben a rajongókkal való megfelelő kapcsolattartás, az interjúk jellegzetességéről, az ígéretek megfogalmazásáról és a jó kommunikáció jellegzetességéről számol be.

Az utolsó fejezet hasonlóan az előzőhöz nem annyira az e-sportolás jellemzőiről szól, hanem a vezetőkről és az irányítókról. Méghozzá azon pontokat hangsúlyozza, amelyek a jó vezetői tulajdonságokat jelentik (p. 183184), illetve azon verbális, nonverbális és viselkedési jellemzőket, amelyek alapján azonosítani tudjuk a kiváló vezetőket (p. 185- 
186). A könyv végén a kulcsgondolatok összefoglalásával zár a szerző, amelyek azon kiemelt mondatok, amik a könyv magját, a szerző által legfontosabbnak ítélt tulajdonságokat tartalmazza, így elősegítve a későbbi könnyebb felelevenítését a könyv tartal-mának.

Összességében egy érdekes és tartalmas könyv, melyben sok hasznos téma, kérdés és példa felvetül, amelyek legtöbbje nem csak esportokban használható fel, hanem a hagyományos sportok terén is, sőt saját hétköznapi életünkben is tudunk belőle alkalmazni. Az érthetőség és a kommerciális jellege miatt a nyelvezet hétköznapi illetve szubjektív, mely jellegéből indulva érthetô, azonban a tudományosságából sokat veszít azáltal, hogy viszonylag kevés hivatkozást használ fel a könyv folyamán. Természetesen a könyv célközönsége nem az akadémikus közeg, mindazonáltal az egyes elméletek bemutatásánál egy, vagy akár több kutatás megemlítése segíthet mindenkinek jobban elmélyülni a témában, azáltal hogy lehetôséget kap a számára érdekelt téma mélyebb megismerésének a szakirodalom visszakövetése által.
Zárásként ajánlom a könyvet minden esportolónak, illetve e-sportolni vágyó személynek, sôt akár hagyományos sportolóknak is, ahogy olyan személyeknek, akik jobban meg szeretnék ismerni az e-sport világát. Tudományosság szempontjából ajánlom minden olvasónak, hogy kritikus szemmel olvassa a leírtakat, a hivatkozás nélküli elméletek, ötletek esetén ajánlott az adott témában végrehajtott empirikus kutatások után olvasni, ezáltal kiegészítve és teljessé téve a könyv tartalmát.

\section{Irodalom}

Berne, E. (1964). Games People Play: The Psychology of Human Relationships. Grove Press

Csíkszentmihályi, M (1991.) Flow: The psychology of optimal experience. HarperPerennial New York

Kübler-Ross. E. (2009). On death and dying? What the dying have to teach doctors, nurses, clergy, and their own families. Taylor \& Francis 